\title{
PENENTUAN KONDISI OPTIMUM DALAM PENANDAAN LIGAN EDTMP DENGAN RADIOISOTOP ${ }^{170} \mathrm{Tm}$
}

\author{
Azmairit Aziz, Marlina, Muhamad Basit Febrian \\ Pusat Teknologi Nuklir Bahan dan Radiometri - BATAN \\ Jl. Tamansari 71 Bandung, 40132, e-mail : azmairit@batan-bdg.go.id
}

Diterima 16 Juli 2010, diterima dalam bentuk perbaikan 31 Agustus 2010, disetujui 1 September 2010

\begin{abstract}
ABSTRAK
PENENTUAN KONDISI OPTIMUM DALAM PENANDAAN LIGAN EDTMP DENGAN RADIOISOTOP ${ }^{170} \mathrm{Tm}$. Tulium-170 $\left({ }^{170} \mathrm{Tm}\right)$ merupakan salah satu radioisotop yang dapat digunakan untuk terapi paliatif karena merupakan pemancar- $\beta$ yang memiliki $T_{1 / 2}=128,4$ hari dan $E_{\beta \text { (maksimum) }}$ sebesar 0,968 MeV. Radioisotop ${ }^{170} \mathrm{Tm}$ selain pemancar$\beta$ juga memancarkan sinar- $\gamma$ dengan energi sebesar $84 \mathrm{keV}(3,26 \%)$ yang dapat dimanfaatkan untuk penyidikan (imaging) selama terapi berlangsung. Ligan etilendiamintetrametilen fosfonat (EDTMP) dapat ditandai dengan radioisotop ${ }^{170} \mathrm{Tm}$ sebagai radiofarmaka alternatif untuk penghilang rasa sakit (paliatif) akibat metastase kanker ke tulang menggantikan ${ }^{89} \mathrm{SrCl}_{2}$. Telah dilakukan penentuan kondisi optimum dalam penandaan ligan EDTMP dengan radioisotop ${ }^{170} \mathrm{Tm}$ berdasarkan variasi beberapa parameter yang berpengaruh dalam reaksi penandaan, yaitu jumlah ligan EDTMP, $p H$ penandaan dan waktu inkubasi. Senyawa bertanda ${ }^{170} \mathrm{Tm}$-EDTMP yang diperoleh ditentukan efisiensi penandaan melalui pemeriksaan kemurnian radiokimianya dengan cara kromatografi kertas dan elektroforesis kertas. Kondisi optimum penandaan diperoleh pada $\mathrm{pH} 7$ dengan jumlah ligan EDTMP sebanyak $2 \mathrm{mg}$ dan waktu inkubasi selama 15 menit pada temperatur kamar. Kompleks yang terbentuk memberikan efisiensi penandaan maksimum sebesar 99,23 $\pm 0,27 \%$. Berdasarkan hasil yang diperoleh, ligan EDTMP dapat ditandai dengan radioisotop ${ }^{170} \mathrm{Tm}$ dengan efisiensi penandaan yang tinggi (di atas 95\%).
\end{abstract}

Kata kunci : radioisotop, tulium-170 $\left({ }^{170} \mathrm{Tm}\right)$, etilendiamintetrametilen fosfonat (EDTMP), paliatif.

\section{ABSTRACT}

THE DETERMINATION OF OPTIMUM CONDITION ON LABELLING OF EDTMP LIGAND WITH ${ }^{170} \mathrm{Tm}$ RADIOISOTOPE. Thulium-170 $\left({ }^{170} \mathrm{Tm}\right)$ is one of radioisotopes that can be used for bone pain palliation due to its $\beta$ particle emission $\left(T_{1 / 2}=128.4 d, E_{\beta(\max )}=0,968 \mathrm{MeV}\right)$. Beside that, this radioisotope also emits $\gamma$-rays of $84 \mathrm{keV}$ (3.26\%) which are suitable energy for imaging as long as therapeutic applications. The ligand of ethylenediaminetetramethylene phosphonic acid (EDTMP) could be labelled with radioisotope of ${ }^{170} \mathrm{Tm}$ as an alternative radiopharmaceutical for bone pain palliation due to bone metastases instead of ${ }^{89} \mathrm{SrCl}_{2}$. The determination of optimum condition on labelling of EDTMP with ${ }^{170} \mathrm{Tm}$ has been studied. Reaction parameters in labelling conditions i.e. the amount of EDTMP ligand, the $\mathrm{pH}$ of labeling and the incubation time were varied in order to obtain high labelling efficiency of ${ }^{170} \mathrm{Tm}$-EDTMP. The labelling efficiency was obtained by radiochemical purity that was determined by paper chromatography and paper electrophoresis techniques. The optimum labelling condition was obtained at $\mathrm{pH} 7$ by using of $2 \mathrm{mg}$ of EDTMP ligand and 15 minutes incubation time at room temperature. The complex formed was gave maximum labelling efficiency of $99.23 \pm 0.27 \%$. Owing to the results, EDTMP ligand can be labelled with ${ }^{170} \mathrm{Tm}$ radioisotope with labelling efficiency more than $95 \%$.

Keywords : radioisotope, thulium-170 $\left({ }^{170} \mathrm{Tm}\right)$, ethylenediaminetetramethylene phosphonic acid (EDTMP), palliative.

\section{PENDAHULUAN}

Sekitar $80 \%$ dari pasien yang menderita kanker payudara, prostat dan paru-paru mengalami metastase kanker ke tulang. Kanker ini dapat menyebabkan rasa nyeri yang sangat kuat sehingga dapat menurunkan kualitas hidup pasien ${ }^{[1-5]}$.

Untuk mengatasi gejala ini, berbagai cara telah dilakukan oleh dokter di rumah sakit, yaitu dengan cara pemberian obat analgesik (narkotik), hormon terapi, kemoterapi dan radioterapi. Pemberian radiofarmaka pemancar- $\beta$ secara sistemik merupakan cara yang paling efektif untuk menghilangkan rasa sakit akibat metastase kanker ke tulang ${ }^{[1]}$. 
Beberapa radiofarmaka untuk keperluan terapi yang ditandai dengan radioisotop pemancar- $\beta$, seperti ${ }^{89} \mathrm{SrCl}_{2},{ }^{153} \mathrm{Sm}$-EDTMP, ${ }^{186} \mathrm{Re}$-HEDP dan ${ }^{117 \mathrm{~m}} \mathrm{Sn}$-DTPA telah digunakan di bidang kedokteran nuklir sebagai radiofarmaka penghilang rasa sakit akibat metastase kanker ke tulang ${ }^{[1,5-7]}$.

Radiofarmaka ${ }^{89} \mathrm{SrCl}_{2}$ dan ${ }^{153} \mathrm{Sm}$-EDTMP lebih banyak digunakan di bidang kedokteran nuklir dibanding radiofarmaka lainnya. Radiofarmaka ${ }^{89} \mathrm{SrCl}_{2}$ memiliki keunggulan dalam hal waktu paronya yang relatif lebih panjang yaitu selama 50,5 hari, sehingga memungkinkan untuk menyediakan radiofarmaka tersebut ke seluruh dunia tanpa banyak kehilangan radioaktivitasnya akibat peluruhan zat radioaktif selama di perjalanan. Akan tetapi, radiofarmaka ${ }^{89} \mathrm{SrCl}_{2}$ memiliki kekurangan, yaitu biaya produksinya yang lebih tinggi dan terbatasnya kapasitas produksi radioisotop ${ }^{89} \mathrm{SrCl}_{2}$. Di samping itu, radionuklida ${ }^{89} \mathrm{Sr}$ memiliki energi partikel- $\beta$ lebih besar $\left(\mathrm{E}_{\beta}\right.$ ${ }_{\text {maks }}=1,49 \mathrm{MeV}$ ), sehingga dapat memberikan dosis yang tinggi pada sumsum tulang dan akhirnya dapat menekan pembentukan sel-sel darah. Hal ini dapat mengakibatkan terjadinya penurunan jumlah trombosit dan leukosit dalam darah ${ }^{[1,2,8,9]}$.

Radiofarmaka ${ }^{153} \mathrm{Sm}$-EDTMP lebih unggul dibanding ${ }^{89} \mathrm{SrCl}_{2}$ karena sifat fisika yang dimiliki radioisotop ${ }^{153} \mathrm{Sm}$. Radioisotop ${ }^{153} \mathrm{Sm}$ memiliki energi partikel- $\beta$ lebih rendah $\left(\mathrm{E}_{\beta \text { maks }}=0,81 \mathrm{MeV}\right)$ dibandingkan radioisotop ${ }^{89} \mathrm{Sr}$, sehingga dapat memberikan dosis yang lebih rendah pada sumsum tulang. Di samping itu, radiofarmaka ${ }^{153} \mathrm{Sm}$-EDTMP memungkinkan untuk diinjeksikan dengan aktivitas yang lebih besar untuk mendapatkan dosis radiasi yang optimal pada jaringan kanker tanpa mengakibatkan toksisitas pada sumsum tulang. Radioisotop ${ }^{153} \mathrm{Sm}$ dapat diproduksi dengan menggunakan reaktor riset yang memiliki fluks neutron menengah dengan cara yang mudah dan diperoleh aktivitas yang cukup tinggi dengan aktivitas jenis yang memadai. Akan tetapi, radioisotop ${ }^{53} \mathrm{Sm}$ memiliki waktu paro yang relatif lebih pendek yaitu selama 1,96 hari, sehingga radiofarmaka ${ }^{153} \mathrm{Sm}$-EDTMP hanya memungkinkan untuk disediakan pada rumah sakit yang letaknya dekat dengan tempat produksi ${ }^{[1]}$.

Tulium-170 $\left({ }^{170} \mathrm{Tm}\right)$ merupakan radioisotop dari golongan lantanida yang dapat digunakan untuk terapi karena merupakan pemancar- $\beta$ yang memiliki $T_{1 / 2}$ selama 128,4 hari dan $E_{\beta}$ (maks) sebesar $0,968 \mathrm{MeV}$. Di samping itu, radioisotop ${ }^{170} \mathrm{Tm}$ juga memancarkan sinar- $\gamma$ dengan energi yang cocok untuk penyidikan (imaging) selama terapi berlangsung $\left(E_{\gamma}=84 \mathrm{keV}(3,26 \%)\right)^{[1,10]}$.

Radioisotop ${ }^{170} \mathrm{Tm}$ memiliki waktu paro yang lebih panjang dibanding ${ }^{89} \mathrm{Sr}$, sehingga memungkinkan untuk menyediakan radioisotop tersebut pada rumah sakit yang letaknya jauh dari tempat produksi. Di samping itu, radioisotop ${ }^{170} \mathrm{Tm}$ memiliki $\mathrm{E}_{\beta \text { (maks) }}$ yang lebih rendah dibanding ${ }^{89} \mathrm{Sr}$, sehingga dosis yang diberikan pada sumsum tulang akan menjadi lebih rendah. Radioisotop ${ }^{170} \mathrm{Tm}$ dapat diproduksi dengan cara yang relatif mudah menggunakan bahan sasaran tulium oksida alam melalui reaksi inti $(n, \gamma)$ di reaktor riset yang memiliki fluks neutron sedang. Bahan sasaran ${ }^{169} \mathrm{Tm}$ memiliki kelimpahan isotop di alam sangat tinggi, yaitu sebesar $100 \%$ dan tampang lintang neutron termal cukup besar, yaitu sebesar 105 barn, sehingga memungkinkan untuk memperoleh radioisotop ${ }^{170} \mathrm{Tm}$ dengan aktivitas jenis yang memadai dan kemurnian radionuklida yang tinggi. Berdasarkan sifat radionuklidanya tersebut, radioisotop ${ }^{170} \mathrm{Tm}$ lebih unggul dibanding ${ }^{89} \mathrm{SrCl}_{2}$ dan dapat digunakan sebagai radioisotop alternatif dalam pengembangan radiofarmaka baru untuk paliatif ${ }^{11}$.

Ligan etilendiamintetrametilen fosfonat (EDTMP) merupakan senyawa turunan fosfonat dengan struktur dasar P-C-N-C-P dan dapat membentuk senyawa kompleks yang stabil dengan berbagai radionuklida. Ligan ini memungkinkan untuk ditandai dengan radionuklida ${ }^{170} \mathrm{Tm}$ menghasilkan senyawa bertanda ${ }^{170} \mathrm{Tm}$-EDTMP. Senyawa bertanda tersebut dapat digunakan sebagai radiofarmaka alternatif penghilang rasa sakit (paliatif) akibat metastase kanker ke tulang pengganti ${ }^{89} \mathrm{SrCl}_{2}^{[1]}$. Dalam makalah ini dikemukakan penentuan kondisi optimum dalam penandaan ligan etilendiaminterametilen fosfonat dengan radioisotop ${ }^{170} \mathrm{Tm}$. Untuk mendapatkan senyawa bertanda ${ }^{170} \mathrm{Tm}$-EDTMP dengan efisiensi penandaan yang tinggi, maka dilakukan variasi beberapa parameter yang berpengaruh dalam reaksi penandaan, yaitu jumlah ligan EDTMP, pH penandaan dan waktu inkubasi. Senyawa bertanda ${ }^{170} \mathrm{Tm}$-EDTMP yang diperoleh ditentukan efisiensi penandaan melalui pemeriksaan kemurnian radiokimianya dengan berbagai sistem kromatografi. 


\section{METODOLOGI}

\section{Bahan dan peralatan}

Bahan yang digunakan dalam penelitian ini adalah tulium oksida $\left(\mathrm{Tm}_{2} \mathrm{O}_{3}\right)$ alam (buatan Aldich), asam klorida, natrium hidroksida, natrium bikarbonat, dinatrium hidrogen fosfat, natrium dihidrogen fosfat, asam asetat, aseton, amoniak, metanol serta pereaksi-pereaksi lain buatan E.Merck. Ligan etilendiamintetrametilen fosfonat (EDTMP) buatan TCl. Akuabides steril dan NaCl fisiologis steril (0,9\%) buatan IPHA.

Bahan penunjang yang digunakan adalah kertas indikator $\mathrm{pH}$ universal, kertas kromatografi Whatman 1, Whatman 3MM dan TLC SG 60.

Peralatan yang digunakan terdiri dari seperangkat alat kromatografi lapisan tipis dan kromatografi kertas, peralatan gelas, pencacah-y saluran tunggal, dan seperangkat alat elektroforesis kertas.

\section{Tata kerja}

\section{Iradiasi tulium oksida $\left(\mathrm{Tm}_{2} \mathrm{O}_{3}\right)$}

Sebanyak $50 \mathrm{mg}$ serbuk $\mathrm{Tm}_{2} \mathrm{O}_{3}$ dimasukkan ke dalam tabung kuarsa, lalu ditutup dengan cara pengelasan. Tabung kuarsa dimasukkan ke dalam inner capsule yang terbuat dari bahan aluminium nuclear grade, lalu ditutup dengan cara pengelasan. Uji kebocoran dilakukan terhadap inner capsule dengan metode gelembung dalam media air sampai tekanan $30 \mathrm{inci} \mathrm{Hg}$. Setelah lolos uji kebocoran, kemudian inner capsule dimasukkan ke dalam outer capsule untuk diiradiasi. Iradiasi dilakukan di RSG-GA Siwabessy Serpong selama \pm 5 hari pada posisi iradiasi CIP dengan fluks neutron termal sebesar $1,3 \times 10^{14} \mathrm{n} \cdot \mathrm{cm}^{-2} \cdot \mathrm{det}^{-1}$.

\section{Preparasi larutan radioisotop ${ }^{170} \mathrm{TmCl}_{3}$}

Sebanyak 50 mg serbuk $\mathrm{Tm}_{2} \mathrm{O}_{3}$ hasil iradiasi selama \pm 5 hari dimasukkan ke dalam beker gelas 100 $\mathrm{mL}$, kemudian dilarutkan dalam $5 \mathrm{~mL}$ larutan $\mathrm{HCl} 1 \mathrm{~N}$ sambil dipanaskan perlahan-lahan sampai hampir kering, lalu dilarutkan kembali dalam $5 \mathrm{~mL}$ akuabides steril.

\section{Penentuan kondisi optimum preparasi senyawa bertanda ${ }^{170} \mathrm{Tm}$-EDTMP}

Untuk mendapatkan senyawa bertanda ${ }^{170} \mathrm{Tm}$-EDTMP dengan efisiensi penandaan yang tinggi, dilakukan variasi beberapa parameter yang berpengaruh dalam reaksi penandaan, yaitu jumlah ligan EDTMP (1; $2 ; 4 ; 6 ; 8$ dan $10 \mathrm{mg})$; $\mathrm{pH}$ penandaan $(2,3,4,5,6,7,8$ dan 9$)$ dan waktu inkubasi pada temperatur kamar $(0,15$, 30,45 dan 60 menit).

\section{Preparasi senyawa bertanda ${ }^{170} \mathrm{Tm}$-EDTMP}

Sebanyak $2 \mathrm{mg}$ ligan EDTMP dilarutkan dalam 0,2 ml larutan $\mathrm{NaHCO}_{3} 0,5 \mathrm{M}(\mathrm{pH}$ 9), lalu ditambahkan sebanyak $795 \mu \mathrm{L}$ larutan $\mathrm{NaCl}$ fisiologis $(0,9 \%)$ dan $5 \mu \mathrm{L}$ larutan ${ }^{170} \mathrm{TmCl}_{3}( \pm 0,1 \mathrm{mCi})$. Kemudian pH ditepatkan menjadi 7 dengan penambahan larutan $\mathrm{HCl} 1 \mathrm{~N}$ atau $\mathrm{NaOH} 1 \mathrm{~N}$. Larutan diinkubasi selama 15 menit pada temperatur kamar, kemudian ditentukan kemurnian radiokimianya dengan metode kromatografi lapisan tipis, kromatografi kertas dan elektroforesis kertas.

\section{Pemeriksaan kemurnian radiokimia senyawa bertanda ${ }^{170} \mathrm{Tm}$-EDTMP}

Kemurnian radiokimia senyawa ${ }^{170} \mathrm{Tm}$-EDTMP ditentukan dengan metode kromatografi lapisan tipis $(\mathrm{KLT})$ dengan menggunakan pelat silika gel $60(2 \times 10 \mathrm{~cm})$ sebagai fase diam dan aseton sebagai fase gerak. Metode kromatografi kertas dilakukan dengan menggunakan kertas kromatografi Whatman $3 \mathrm{MM}(2 \times 10 \mathrm{~cm})$, Whatman $3 \mathrm{MM}(2 \times 20 \mathrm{~cm})$ dan Whatman $1(2 \times 25 \mathrm{~cm})$ sebagai fase diam dan larutan $\mathrm{NaCl}$ fisiologis $(0,9 \%)$, asam asetat 50\%, aseton serta larutan amoniak : metanol : air (1:10:20) sebagai fase gerak. Sedangkan metode elektroforesis kertas dilakukan dengan menggunakan pelat pendukung kertas kromatografi Whatman $3 \mathrm{MM}(2 \mathrm{x}$ $38 \mathrm{~cm}$ ) dan larutan dapar fosfat $0,02 \mathrm{M} \mathrm{pH} \mathrm{7,5}$ sebagai larutan elektrolitnya, pemisahan dilakukan selama 1 jam pada tegangan 350 volt. Kemudian kertas kromatografi dan kertas elektroforesis dikeringkan, dipotong-potong dan dicacah dengan pencacah- $y$ saluran tunggal. 


\section{HASIL DAN PEMBAHASAN}

Senyawa bertanda yang diperoleh dari hasil penandaan ligan EDTMP dengan ${ }^{170} \mathrm{TmCl}_{3}$ diharapkan memiliki kemurnian radiokimia yang tinggi. Senyawa bertanda yang diperoleh diharapkan hanya berada dalam bentuk senyawa kimia yang diharapkan, yaitu ${ }^{170} \mathrm{Tm}$-EDTMP. Senyawa lain sebagai pengotor radiokimia yang mungkin ada di dalam senyawa bertanda yang diperoleh adalah ${ }^{170} \mathrm{TmCl}_{3}$ bebas. Hasil pemisahan senyawa bertanda ${ }^{170} \mathrm{Tm}$-EDTMP dan pengotor radiokimia $\left({ }^{170} \mathrm{TmCl}_{3}\right)$ pada berbagai sistem kromatografi dapat dilihat pada Tabel 1.

Tabel 1. Nilai Rf senyawa bertanda ${ }^{170} \mathrm{Tm}$-EDTMP dengan berbagai sistem kromatografi kertas dan kromatografi lapisan tipis.

\begin{tabular}{|c|c|c|c|c|c|c|}
\hline \multirow{2}{*}{ No. } & \multicolumn{2}{|c|}{ Sistem kromatografi } & \multicolumn{2}{|c|}{$\mathrm{Rf}$} & \multirow{2}{*}{$\begin{array}{l}\text { Waktu elusi } \\
\text { (menit) }\end{array}$} & \multirow{2}{*}{ Keterangan } \\
\hline & Fase diam & Fase gerak & ${ }^{170} \mathrm{Tm}$-EDTMP & ${ }^{170} \mathrm{TmCl}_{3}$ & & \\
\hline 1. & $\begin{array}{l}\text { TLC SG } 60 \\
(2 \times 10 \mathrm{~cm})\end{array}$ & Aseton & 0 & 0 & 30 & $\begin{array}{l}\text { tidak dapat } \\
\text { digunakan }\end{array}$ \\
\hline 2. & $\begin{array}{l}\text { Kertas kromatografi Whatman } \\
3 \mathrm{MM}(2 \times 20 \mathrm{~cm})\end{array}$ & Aseton & 0 & 0 & 35 & $\begin{array}{l}\text { tidak dapat } \\
\text { digunakan }\end{array}$ \\
\hline 3. & $\begin{array}{l}\text { Kertas kromatografi Whatman } 1 \\
(2 \times 25 \mathrm{~cm})\end{array}$ & $\mathrm{NaCl} 0,9 \%$ & $0,7-0,9$ & $0,6-0,8$ & 110 & $\begin{array}{l}\text { tidak dapat } \\
\text { digunakan }\end{array}$ \\
\hline 4. & $\begin{array}{l}\text { Kertas kromatografi Whatman } \\
3 \mathrm{MM}(2 \times 20 \mathrm{~cm})\end{array}$ & $\begin{array}{l}\text { Asam asetat } \\
50 \%\end{array}$ & $0-0,4$ & $0,3-0,8$ & 160 & $\begin{array}{l}\text { tidak dapat } \\
\text { digunakan }\end{array}$ \\
\hline 5. & $\begin{array}{l}\text { Kertas kromatografi Whatman } \\
3 \mathrm{MM}(2 \times 10 \mathrm{~cm})\end{array}$ & $\begin{array}{l}\text { Amoniak: } \\
\text { metanol:air } \\
(1: 10: 20)\end{array}$ & $0,8-0,9$ & 0 & 30 & $\begin{array}{l}\text { dapat } \\
\text { digunakan }\end{array}$ \\
\hline
\end{tabular}

Pada Tabel 1 terlihat bahwa sistem kromatografi nomor 1 dan 2 tidak dapat digunakan karena tidak dapat memisahkan dengan baik senyawa kompleks ${ }^{170} \mathrm{Tm}$-EDTMP dari senyawa ${ }^{170} \mathrm{TmCl}_{3}$. Pada kedua sistem tersebut, senyawa ${ }^{170} \mathrm{Tm}$-EDTMP dan ${ }^{170} \mathrm{TmCl}_{3}$ tetap berada pada titik nol $(\mathrm{Rf}=0)$. Akan tetapi, pada sistem kromatografi nomor 3 dan 4, kedua senyawa tersebut bergerak ke arah aliran fase gerak, tetapi tidak dapat memisahkan dengan baik senyawa kompleks ${ }^{170} \mathrm{Tm}$-EDTMP dari senyawa ${ }^{170} \mathrm{TmCl}_{3}$, sehingga sistem kromatografi nomor 3 dan 4 juga tidak dapat digunakan untuk memisahkan kedua senyawa tersebut. Pada sistem kromatografi nomor 5 , senyawa kompleks ${ }^{170} \mathrm{Tm}$-EDTMP dapat dipisahkan dengan baik dari senyawa ${ }^{170} \mathrm{TmCl}_{3}$. Hasil kromatografi kertas senyawa kompleks ${ }^{170} \mathrm{Tm}$-EDTMP dan senyawa ${ }^{170} \mathrm{TmCl}_{3}$ dengan menggunakan sistem kromatografi nomor 5 terlihat seperti pada Gambar 1.

Pada Gambar 1 terlihat senyawa ${ }^{170} \mathrm{Tm}$-EDTMP bergerak ke arah aliran fase gerak dengan $\mathrm{Rf}=0,8-$ 0,9 sedangkan pengotor radiokimianya, yaitu senyawa ${ }^{170} \mathrm{TmCl}_{3}$ tetap berada pada titik nol (Rf=0).

Hasil pemisahan senyawa ${ }^{170} \mathrm{Tm}$-EDTMP dan ${ }^{170} \mathrm{TmCl}_{3}$ dengan menggunakan metode elektroforesis kertas, yaitu dengan menggunakan pelat pendukung kertas kromatografi Whatman $3 \mathrm{MM}(2 \times 38 \mathrm{~cm})$ dan larutan dapar fosfat $0,02 \mathrm{M} \mathrm{pH} \mathrm{7,5}$ sebagai larutan elektrolitnya, diperoleh senyawa ${ }^{170} \mathrm{TmCl}_{3}$ tidak bermuatan dan tetap berada pada titik nol (Rf $=0)$, sedangkan senyawa kompleks ${ }^{170} \mathrm{Tm}$-EDTMP bergerak ke arah anoda yang menunjukkan bahwa senyawa kompleks ${ }^{170} \mathrm{Tm}$-EDTMP tersebut bermuatan negatif dengan $\mathrm{Rf}=0,4-0,5$. 


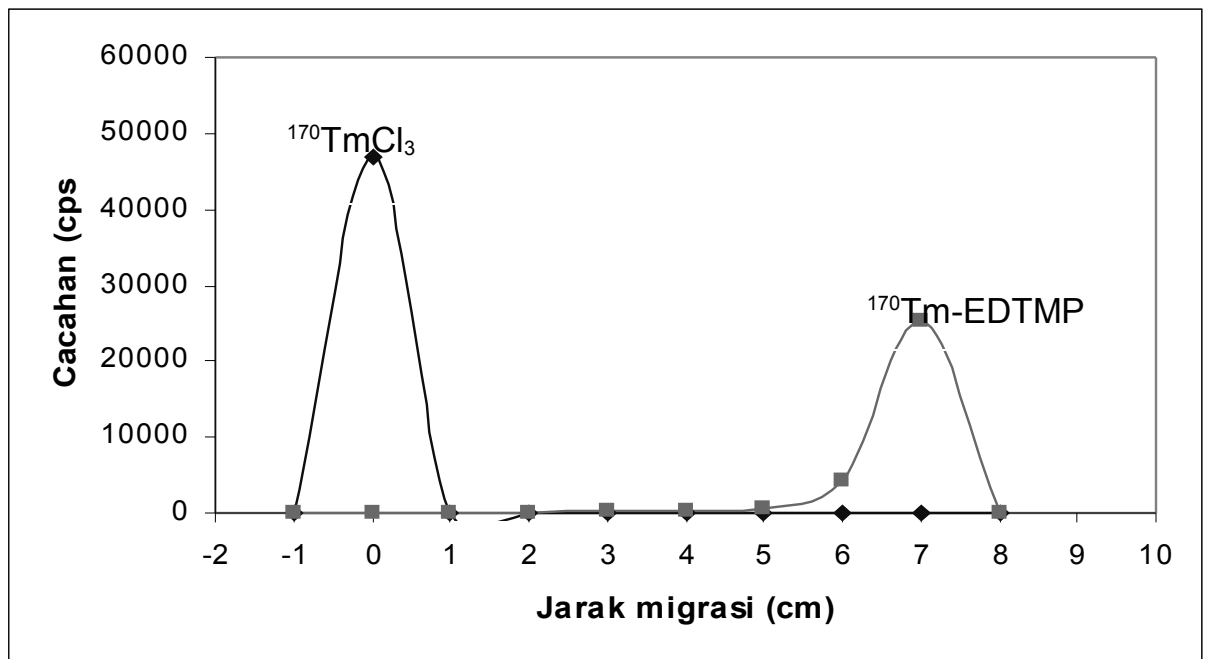

Gambar 1. Hasil kromatografi kertas senyawa kompleks ${ }^{170} \mathrm{Tm}$-EDTMP dan senyawa ${ }^{170} \mathrm{TmCl}_{3}$ dengan menggunakan kertas kromatografi Whatman $3 \mathrm{MM}$ sebagai fase diam dan campuran amoniak : metanol : air $=1: 10: 20$ sebagai fase gerak.

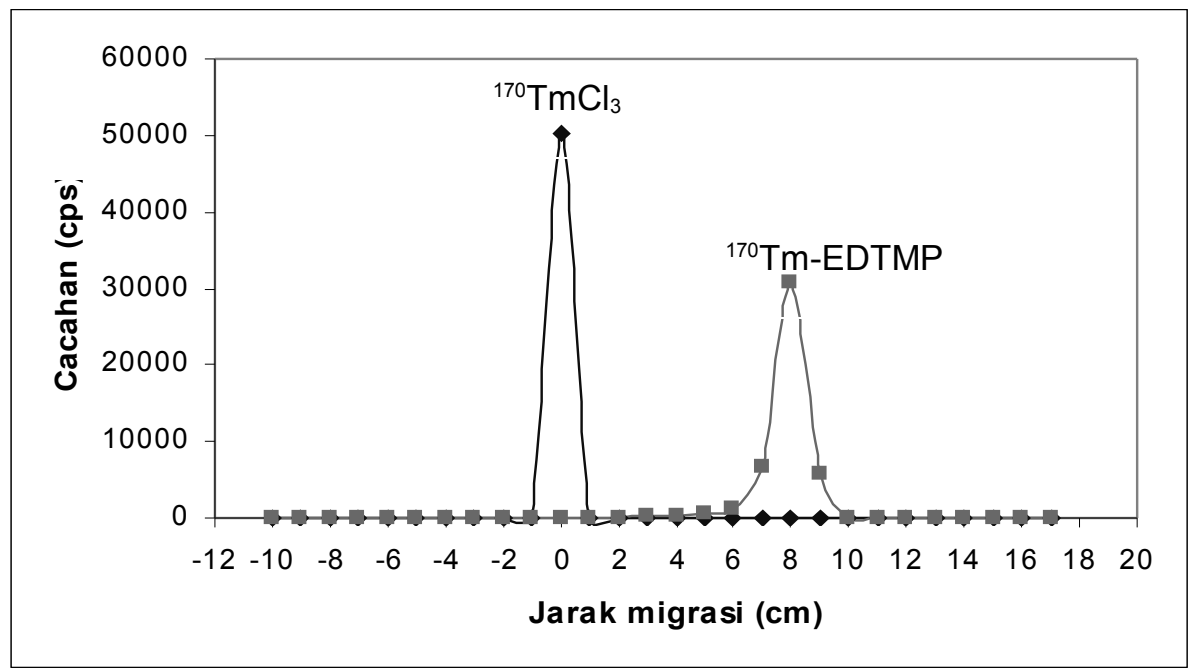

Gambar 2. Hasil elektroforesis kertas senyawa kompleks ${ }^{170} \mathrm{Tm}$-EDTMP dan senyawa ${ }^{170} \mathrm{TmCl}_{3}$.

Gambar 2 memperlihatkan hasil elektroforesis kertas senyawa kompleks ${ }^{170} \mathrm{Tm}$-EDTMP dan senyawa ${ }^{170} \mathrm{TmCl}_{3}$. Hasil pemisahan dengan menggunakan metode kromatografi kertas dan elektroforesis kertas digunakan untuk menentukan kemurnian radiokimia senyawa bertanda ${ }^{170} \mathrm{Tm}$-EDTMP.

Struktur kimia senyawa kompleks ${ }^{170} \mathrm{Tm}$-EDTMP yang diperoleh diperkirakan mirip dengan senyawa kompleks ${ }^{153} \mathrm{Sm}$-EDTMP karena isotop tulium berada dalam satu golongan dengan samarium pada tabel periodik, yaitu pada golongan lantanida dengan bilangan oksidasi +3 . Struktur kimia senyawa bertanda ${ }^{170} \mathrm{Tm}$ EDTMP terlihat seperti pada Gambar 3.

Untuk mendapatkan kondisi optimum penandaan senyawa ${ }^{170} \mathrm{Tm}$-EDTMP, pertama-tama dilakukan dengan cara memvariasikan jumlah ligan EDTMP. Efisiensi penandaan ditentukan dengan melihat kemurnian radiokimianya. Gambar 4 memperlihatkan pengaruh jumlah ligan EDTMP terhadap efisiensi penandaan ${ }^{170} \mathrm{Tm}$ EDTMP. Dari hasil percobaan terlihat bahwa penggunaan bahan ligan sebanyak $1 \mathrm{mg}$ diperoleh efisiensi penandaan sebesar $94,45 \%$. Penggunaan jumlah ligan EDTMP sebanyak $2 \mathrm{mg}$, maka efisiensi penandaan yang diperoleh sebesar $99 \%$, sehingga memenuhi syarat untuk penggunaan di bidang kedokteran nuklir $(1,11)$. Semakin bertambah jumlah ligan EDTMP yang digunakan, maka efisiensi penandaan yang diperoleh tidak 
memberikan perbedaan yang signifikan, yaitu masih sekitar $99 \%$. Mengingat segi ekonomis penggunaan bahan ligan, maka dalam penelitian ini penggunaan ligan EDTMP sebanyak $2 \mathrm{mg}$ (perbandingan mol EDTMP : Tm = 18 : 1) dinyatakan sebagai kondisi optimum reaksi dengan efisiensi penandaan sebesar $99,25 \pm 0,25 \%$.

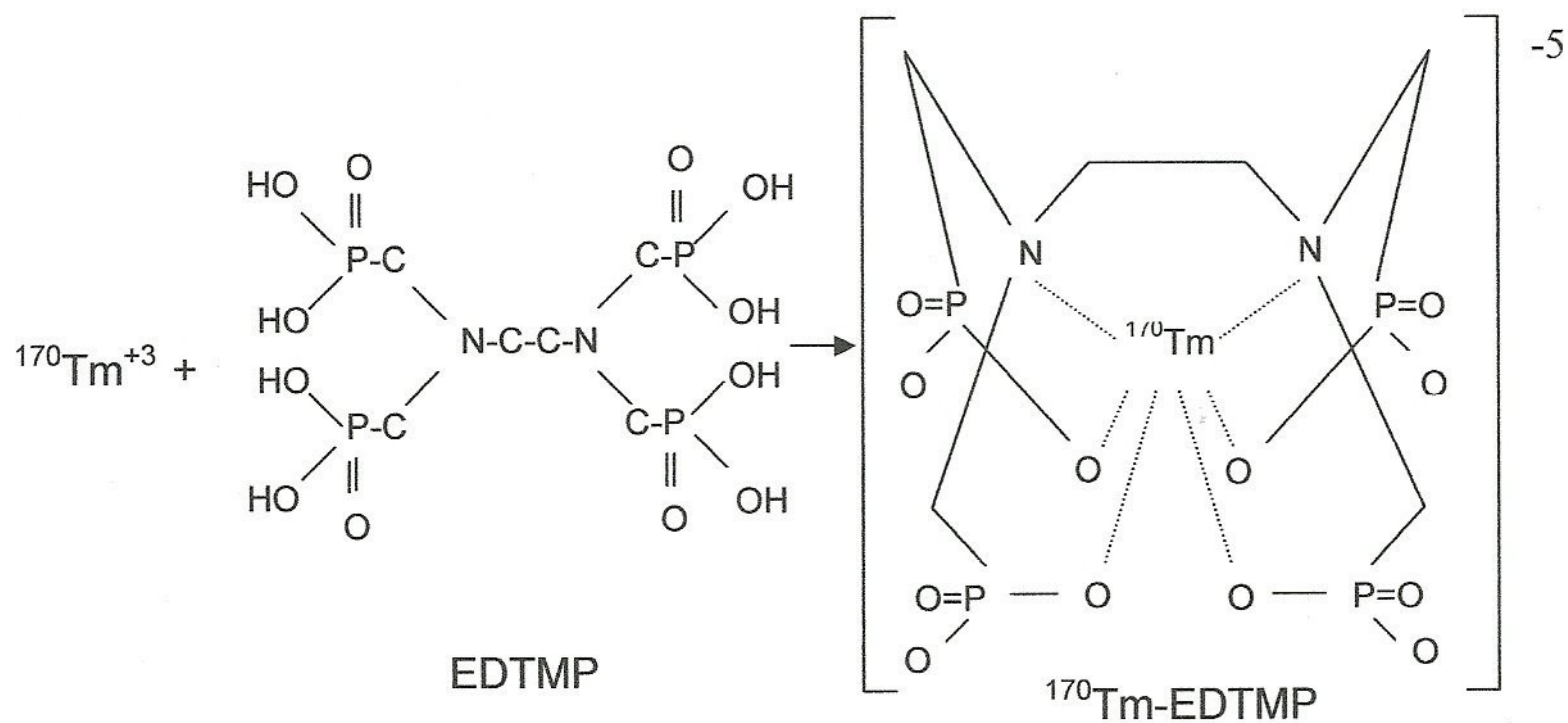

Gambar 3. Struktur kimia senyawa kompleks ${ }^{170} \mathrm{Tm}$-EDTMP

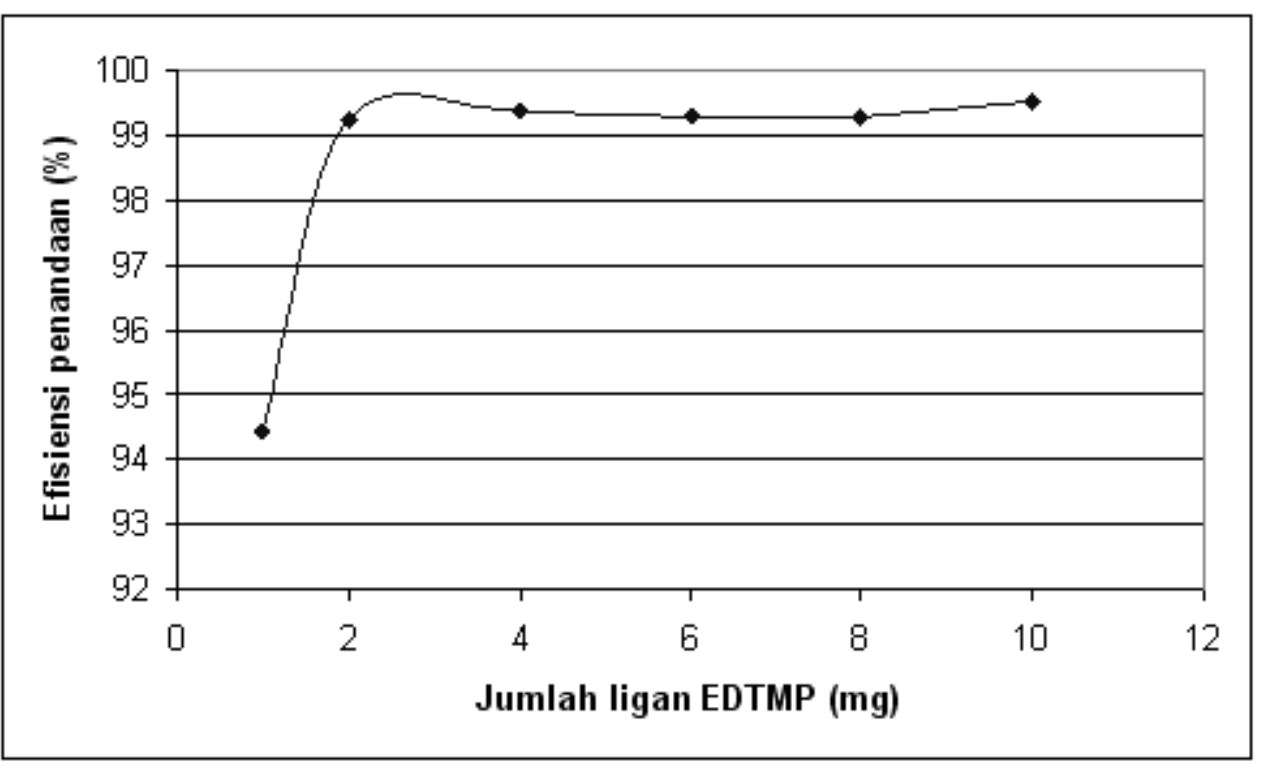

Gambar 4. Pengaruh jumlah ligan terhadap efisiensi penandaan senyawa ${ }^{170} \mathrm{Tm}$-EDTMP. Keterangan : $\mathrm{pH}=7, \mathrm{t}_{\text {inkubasi }}=30$ menit pada temperatur kamar, 


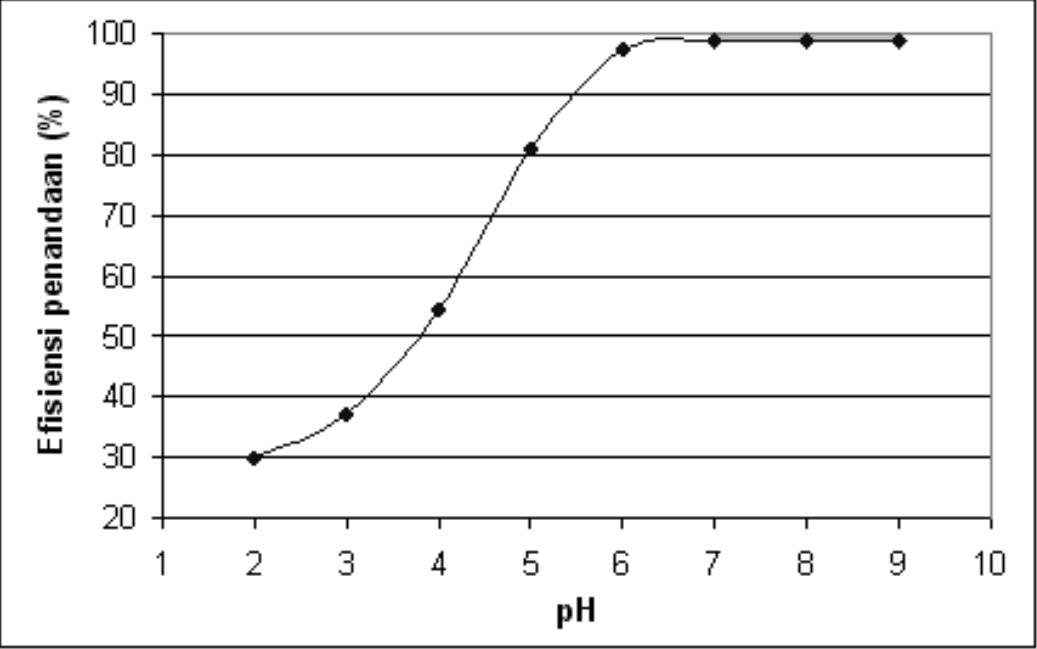

Gambar 5. Pengaruh pH terhadap efisiensi penandaan senyawa ${ }^{170} \mathrm{Tm}$-EDTMP.

Keterangan : $E D T M P=2 \mathrm{mg}, \mathrm{t}_{\text {inkubasi }}=30$ menit pada temperatur kamar.

Dalam pembuatan senyawa bertanda ${ }^{170} \mathrm{Tm}$-EDTMP, $\mathrm{pH}$ merupakan faktor yang sangat penting. Molekul EDTMP sebagai ligan memiliki sepuluh sisi basa, yaitu delapan buah berasal dari atom oksigen gugus fosfonat dan 2 buah berasal dari atom nitrogen. Pada suasana asam, sisi basa tersebut menjadi kurang reaktif bertindak sebagai donor elektron untuk berikatan dengan ion logam membentuk ikatan koordinasi, sehingga efisiensi pembentukan kompleks menjadi rendah. Gambar 5 memperlihatkan pengaruh pH terhadap efisiensi penandaan senyawa ${ }^{170} \mathrm{Tm}$-EDTMP. Pada Gambar 5 terlihat bahwa efisiensi penandaan menurun dengan semakin menurunnya $\mathrm{pH}$ reaksi. Hal ini dapat terlihat dari hasil penandaan yang dilakukan dalam suasana $\mathrm{pH} 2$ - 5 memberikan efisiensi penandaan di bawah $80 \%$. efisiensi penandaan yang tinggi diperoleh pada pH 6 , yaitu sebesar $97 \%$. Pada pH 7-9 diperoleh efisiensi penandaan di atas $98 \%$. Semakin meningkatnya pH reaksi, tidak memberikan perbedaan yang signifikan terhadap efisiensi penandaan. Mengingat campuran reaksi hasil penandaan yang diperoleh mempunyai $\mathrm{pH} \sim 7$, maka pada $\mathrm{pH} 7$ tersebut dinyatakan sebagai kondisi optimum reaksi dengan efisiensi penandaan sebesar $98,68 \pm 0,86 \%$. Hal ini selain dapat mempermudah dalam proses penandaan, senyawa ${ }^{170} \mathrm{Tm}$-EDTMP yang diperoleh mempunyai $\mathrm{pH}$ netral yang mendekati $\mathrm{pH}$ darah.

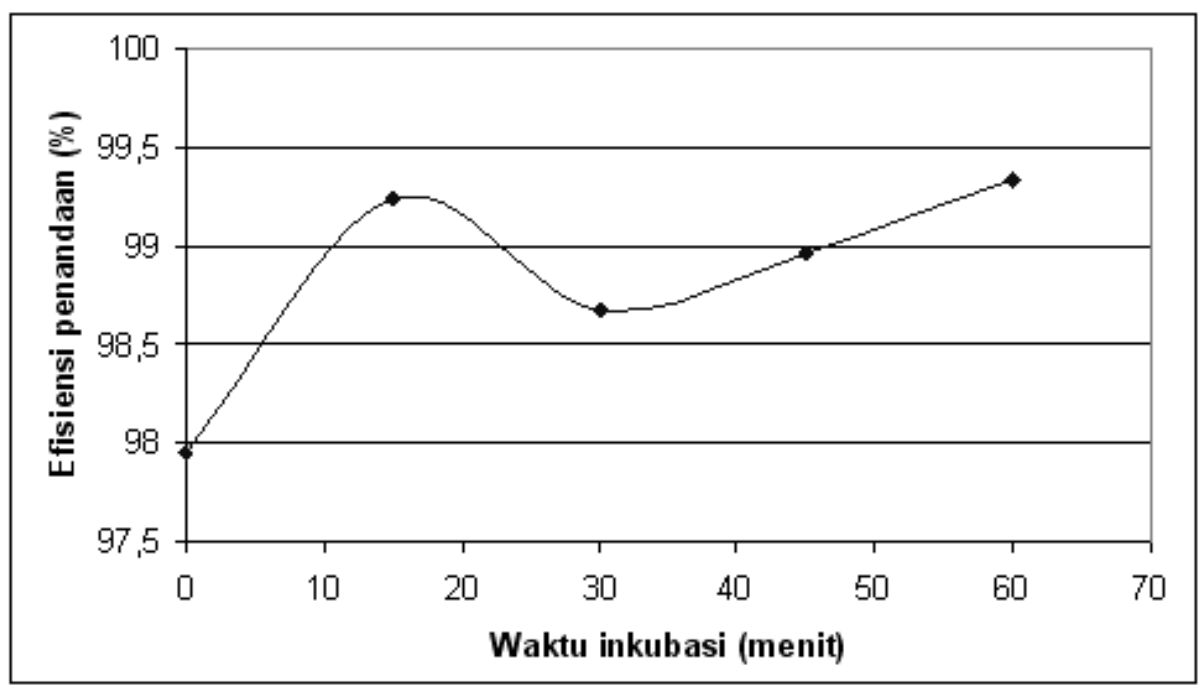

Gambar 6. Pengaruh waktu inkubasi terhadap efisiensi penandaan senyawa ${ }^{170} \mathrm{Tm}$-EDTMP. Keterangan : $E D T M P=2 \mathrm{mg}, \mathrm{pH}=7$. 
Pengaruh waktu inkubasi terhadap efisiensi penandaan senyawa ${ }^{170} \mathrm{Tm}$-EDTMP ditunjukkan pada Gambar 6. Hasil penandaan dengan waktu inkubasi selama 0 menit, diperoleh efisiensi penandaan sebesar $98 \%$, sehingga sudah memenuhi syarat sebagai radiofarmaka untuk terapi (11-13). Penandaan dengan waktu inkubasi selama 15 sampai 60 menit, maka efisiensi penandaan diperoleh sekitar $99 \%$. Hasil penandaan yang diperoleh dengan semakin lamanya waktu inkubasi tidak memberikan kenaikan efisiensi penandaan yang signifikan. Untuk efektifitas waktu, maka dalam penelitian ini penandaan dengan waktu inkubasi selama 15 menit dinyatakan sebagai kondisi optimum reaksi dengan efisiensi penandaan sebesar $99,23 \pm 0,27 \%$.

\section{KESIMPULAN}

1. Senyawa bertanda ${ }^{170} \mathrm{Tm}$-EDTMP dapat dibuat melalui penandaan ligan EDTMP dengan radioisotop ${ }^{170} \mathrm{Tm}$. Senyawa ${ }^{170} \mathrm{Tm}$-EDTMP merupakan senyawa kompleks yang bermuatan negatif. Kondisi optimum penandaan diperoleh pada $\mathrm{pH} 7$ dengan jumlah ligan EDTMP sebanyak $2 \mathrm{mg}$ dan waktu inkubasi selama 15 menit pada temperatur kamar. Senyawa kompleks yang terbentuk memberikan efisiensi penandaan maksimum sebesar $99,23 \pm 0,27 \%$.

2. Berdasarkan hasil yang diperoleh, diharapkan senyawa bertanda 170Tm-EDTMP ini memiliki karakteristik fisiko-kimia yang memenuhi syarat untuk terapi paliatif akibat metastase kanker ke tulang.

\section{UCAPAN TERIMA KASIH}

Penulis mengucapkan terima kasih kepada Sdr. Nana Suherman dan Sdri. Titin Sri Mulyati yang telah membantu penulis di dalam penelitian ini. Penulis juga mengucapkan terima kasih kepada Sdr. Hotman Lubis dan Sdr. Abidin dari PRR-BATAN yang telah membantu dalam persiapan iradiasi target di reaktor Serba Guna G.A. Siwabessy - Serpong.

\section{DAFTAR PUSTAKA}

1. Das T, Chakraborty S, Sarma HD, Tandon P, Banerjee S, Venkatesh M, Pillai MRA. ${ }^{170}$ Tm-EDTMP: a potential cost-effective alternative to ${ }^{89} \mathrm{SrCl}_{2}$ for bone pain palliation. J Nucl Med Biol 2009;36:561-8.

2. Washiyama K, Amano R, Sasaki J, Kinuya S, Tonami N, Shiokawa Y, et al. ${ }^{227}$ Th-EDTMP : A potential therapeutic agent for bone metastasis. J Nucl Med Biol 2004;31(7):901-8.

3. Toegel S, Mien LK, Wadsak W, Eidherr H, Viernstein H, Kluger R, et al. In vitro evaluation of no carrier added, carrier added and cross-complexed $\left.{ }^{90} \mathrm{Y}\right]$-EDTMP provides evidence for a novel "foreign carrier theory". J Nucl Med Biol 2006;33:95-9.

4. Uehara T, Jin ZL, Ogawa K, Akizawa H, Hashimoto K, Nakayama M, et al. Assessment of ${ }^{186}$ Re chelateconjugated bisphosphonate for the development of new radiopharmaceuticals for bones. J Nucl Med Biol 2007;34(1):79-87.

5. Taskar NP, Batraki M, Divgi CR. Radiopharmaceutical therapy for palliation of bone pain from osseous metastases. J Nucl Med 2004;45(8):1358-65.

6. Neves M, Kling A, Lambrecht RM. Radionuclide production for therapy radiopharmaceuticals. J Appl Radiat Isot 2002;57(5):657-64.

7. Riccabona G, Naveda RM, Oberlandstatter M, Donnemiller E, Kendler D. Trial to optimize dosimetry for ${ }^{153}$ Sm-EDTMP therapy to improve therapeutic effects. In: Therapeutic applications of radiopharmaceuticals. IAEA-TECDOC-1228. Proceedings of an International Seminar; 1999 Jan 18-22; Hyderabad, India. Vienna: IAEA; 2001. p. 112-7.

8. Das T, Chakraborty S, Unni PR, Banarjee S, Samuel G, Sarma HD, et al. ${ }^{177}$ Lu-labeled cyclic polyaminophosphonates as potential agents for bone pain palliation. J Appl Radiat Isot 2002;57(2):177-84.

9. Mathew B, Chakraborty S, Das T, Sarma HD, Banerjee S, Samuel G, et al. ${ }^{175} \mathrm{Yb}$ labeled polyaminophosphonates as potential agents for bone pain palliation. J Appl Radiat Isot 2004;60(5):635-42.

10. Ananthakrishnan M. Thulium-170 $\left({ }^{170} \mathrm{Tm}\right)$. In: Manual for reactor produced radioisotopes. IAEATECDOC-1340. Vienna: IAEA; 2003. p. 224-5. 
Penentuan kondisi optimum dalam penandaan ligan EDTMP dengan radioisotop ${ }^{170}$ Tm (Azmairit Aziz, Marlina, Muhamad Basit Febrian)

11. Anonymous. Criteria for palliation of bone metastases - Clinical applications. IAEA-TECDOC-1549. Vienna: IAEA; 2007.

12. Anonymous. Optimization of production and quality control of therapeutic radionuclides and radiopharmaceuticals. IAEA-TECDOC-1114. Vienna: IAEA; 1999.

13. Kothari K, Samuel G, Banarjee S, Unni PR, Sarma HD, Chaudhari PR, et al. ${ }^{186} \mathrm{Re}-1,4,8,11$-tetraaza cyclotetradecyl-1,4,8,11-tetramethylene phosphonic acid: A novel agent for possible use in metastatic bonepain palliation. J Nucl Med Biol 2001;28:709-17. 